\title{
On a new peirosaurid crocodyliform from the Upper Cretaceous, Bauru Group, southeastern Brazil
}

\author{
DIOGENES A. CAMPOS ${ }^{1}$, GUSTAVO R. OLIVEIRA ${ }^{2}$, RODRIGO G. FIGUEIREDO ${ }^{2}$, DOUGLAS RIFF ${ }^{3}$, \\ SERGIO A.K. AZEVEDO ${ }^{2}$, LUCIANA B. CARVALHO ${ }^{2}$ and ALEXANDER W.A. KELLNER ${ }^{2}$ \\ ${ }^{1}$ Departamento Nacional de Produção Mineral, Museu de Ciências da Terra \\ Avenida Pasteur, 404, Urca, 22290-240 Rio de Janeiro, RJ, Brasil \\ ${ }^{2}$ Museu Nacional/Universidade Federal do Rio de Janeiro, Departamento de Geologia e Paleontologia \\ Quinta da Boa Vista, s/n, São Cristóvão, 20940-040 Rio de Janeiro, RJ, Brasil \\ ${ }^{3}$ Universidade Federal de Uberlândia, Instituto de Biologia, Campus Umuarama \\ Bloco 2D - sala 28, Rua Ceará, s/n, Umuarama, 38400-902 Uberlândia, MG, Brasil \\ Manuscript received on December 22, 2010; accepted for publication on January 18, 2011
}

\begin{abstract}
A new crocodyliform from the Upper Cretaceous (Campanian-Maastrichtian) Presidente Prudente Formation of the Bauru Group is described based on two almost complete skulls and mandibles. The material comes from the "Tartaruguito" site, situated at an old railroad between the cities of Pirapozinho and Presidente Prudente, state of São Paulo, Brazil. The new species, Pepesuchus deiseae gen. et sp. nov., is classified in the clade Peirosauridae on the basis of three synapomorphies: the presence of five premaxillary teeth, the anterior two premaxillary alveoli nearly confluent, and the oval cross-section of the jugal along the lower temporal bar. The new taxon increases the outstanding crocodyliform diversity of the Bauru Group, particularly of the Peirosauridae, which might turn out to be one of the most representative clades of gondwanan mesoeucrocodylians.
\end{abstract}

Key words: Pepesuchus, Peirosauridae, Cretaceous, Bauru Group, Brazil.

\section{INTRODUCTION}

The study of crocodyliforms from Brazil has increased tremendously in the last decades, with several new discoveries (e.g., Barbosa et al. 2008, Iori and Carvalho 2009, Kellner et al. 2009). No other stratigraphic unit has provided so many new specimens as the Bauru Group, located in the southeastern portion of the country (Kellner 1998, Kellner and Campos 1999, Candeiro and Martinelli 2006). Among these, the most diversity is found in the Notosuchia, which includes the Baurusuchidae (e.g., Price 1945, Carvalho and Bertini 1999, Campos et al. 2001), and in the Peirosauridae (e.g., Price 1955, Carvalho et al. 2004). The abundance of spec-

Proceedings of the Third Gondwanan Dinosaur Symposium Correspondence to: Diogenes de Almeida Campos

E-mail: diogenes.campos@dnpm.gov.br imens and their disparity of forms allow these clades to be the most studied mesoeucrocodylians from the Bauru Group, with several species described in detail and included in phylogenetic analyses (e.g., Pol 2003, Andrade and Bertini 2008).

So far the crocodyliform fauna from the Bauru Group is composed by the following species: Baurusuchus pachecoi Price, 1945; Baurusuchus salgadoensis Carvalho, Campos \& Nobre, 2005; Baurusuchus albertoi Nascimento \& Zaher, 2010; Sphagesaurus huenei Price, 1950; Sphagesaurus montealtensis Andrade \& Bertini, 2008; Peirosaurus tormini Price, 1955; Itasuchus jesuinoi Price, 1955; Mariliasuchus amarali Carvalho \& Bertini, 1999; Mariliasuchus robustus Nobre, Carvalho, Vasconcellos \& Nava, 2007; Stratiotosuchus maxhechti Campos, Suarez, Riff \& Kellner, 2001; Uberabasuchus 
terrificus Carvalho, Ribeiro \& Avilla, 2004; Adamantinasuchus navae Nobre \& Carvalho, 2006; Montealtosuchus arrudacamposi Carvalho, Vasconcellos \& Tavares, 2007; Armadillosuchus arrudai Marinho \& Carvalho, 2009; and Morrinhosuchus luziae Iori \& Carvalho, 2009. Other specimens currently under description will further increase the diversity of these reptiles from those deposits (e.g., Kellner and Campos 1999).

A good number of species are taxonomically well supported, but there are some exceptions. The most conspicuous one is Brasilosaurus pachecoi von Huene 1931, based on fragmentary material that cannot be diagnosed and is therefore regarded as nomen dubium (Candeiro and Martinelli 2006). Other taxa are in need of careful examination, such as Baurusuchus salgadoensis and Mariliasuchus robustus that potentially could represent Baurusuchus pachecoi and Mariliasuchus amarali, respectively. Uberabasuchus terrificus is another taxon whose validity has been questioned recently (Larsson and Sues 2007).

Here we describe a new crocodyliform from the Upper Cretaceous deposits of the Presidente Prudente Formation (Bauru Group), Pepesuchus deiseae gen. et sp. nov. Based on two nearly complete skulls and lower jaws, the new species is referred to the Peirosauridae, as defined by Larsson and Sues (2007).

\section{GEOLOGICAL SETTING}

The Bauru Group is a large cratonic depression developed during the Upper Cretaceous in the central-southeastern portion of the South American Platform (Fernandes and Coimbra 1996) whose sedimentary rocks overly the basaltic lava flows of the Serra Geral Formation (133Ma to 130Ma, Riccomini 1997). This group is subdivided in several stratigraphic units whose age and distribution are still controversial (e.g., Soares et al. 1980, Fernandes and Coimbra 1996, 2000, Dias-Brito et al. 2001, Zaher et al. 2006).

The holotype of Pepesuchus deiseae gen. et sp. nov. was discovered in an outcrop located near the $\mathrm{Km} 736$ of the old Sorocabana railroad, between the cities of Pirapozinho and Presidente Prudente (coordinates $22^{\circ} 13^{\prime} 14.9^{\prime \prime} \mathrm{S}, 51^{\circ} 25^{\prime} 58.3^{\prime \prime} \mathrm{W}$ ) (Bertini et al. 2006). This site, informally called "Tartaruguito" (free translation - rock made out of turtles), is also the type locality of Bauruemys elegans (Suárez, 1969) (Romano and Azevedo 2007) that is by far the most abundant fossil in this region. This deposit is referred to the Presidente Prudente Formation.

The paratype of Pepesuchus deiseae gen. et sp. nov. (MCT 1788-R) was donated to the Museu de Ciências da Terra (DNPM) by José Martin Suárez. No detailed information about the provenance of this specimen is available other that it was found in the Presidente Prudente - Pirapozinho region. Based on the sedimentary matrix where the material was preserved we believe that it also came from the "Tartaruguito" site, an area where José Martin Suárez did most of his collecting.

\section{SYSTEMATIC PALEONTOLOGY}

\section{Crocodylomorpha Walker 1970 \\ Crocodyliformes Hay 1930 \\ Mesoeucrocodylia Whetstone and Whybrow 1983 \\ SEBECIA Larsson and Sues 2007 \\ PEIROSAURIDAE Gasparini 1982}

Pepesuchus gen. nov

Etymology: In honor of the late Professor José Martin Suárez (known by his colleagues as Pepe), the discoverer and main fossil collector at the "Tartaruguito" outcrop. He led Llewellyn Ivor Price and one of the authors (DAC) to this site for the first time in 1969, from which numerous specimens have been collected since then by several institutions. Pepe assisted the Museu Nacional team in several fieldworks including the one where the type specimen (MN 7005-V) was recovered. He also donated the paratype (MCT 1788-R) to the Museu de Ciências da Terra, along with numerous specimens over the years.

Type species: Pepesuchus deiseae gen. et sp. nov., type by monotypy.

Diagnosis: The same as for the species.

Pepesuchus deiseae sp. nov.

Holotype: Nearly complete skeleton with skull, lower jaw, sacral and caudal vertebrae, osteoderms and limb elements housed at the Museu Nacional/Universidade Federal do Rio de Janeiro under the number MN 7005-V. 
Paratype: A nearly complete skull and lower jaw likely from the same locality of the holotype donated to the Museu de Ciências da Terra - DNPM (MCT 1788-R) by José Martin Suárez.

Type Locality: "Tartaruguito" site, $\mathrm{Km} 736$ of the old Sorocabana railroad, between the cities of Pirapozinho and Presidente Prudente (coordinates $22^{\circ} 13^{\prime} 14.9^{\prime \prime} \mathrm{S}$, $51^{\circ} 25^{\prime} 58.3^{\prime \prime} \mathrm{W}$ ), state of São Paulo.

Horizon: Presidente Prudente Formation, CampanianMaastrichtian (Fernandes and Coimbra 2000).

Diagnosis: Peirosaurid crocodyliform with the following combination of characters that distinguishes it from other members of this clade (autapomorphies are marked with an asterisk): posterolateral process of the squamosal thin and smooth*; postorbital with a comparatively acute anteromedial process*; anterior end of the frontal tapering between the prefrontals; dorsoventral extension of the lacrimal short (approximately $40 \%$ that of the orbit)*; anterior teeth thinner and more elongated than in other peirosaurids*; crowns that lack serrations; anterior teeth of the lower jaw inclined anteriorly; suture between the palatine and the maxilla V-shaped; presence of two alveoli couplets $\left(6^{\text {th }}-7^{\text {th }}\right.$ and $8^{\text {th }}-9^{\text {th }}$ pairs $)$ in the mandible*.

Etymology: In honor of the paleontologist Deise Dias Rêgo Henriques who has maintained the traditional research on vertebrate fossils at the Museu Nacional/UFRJ. She also takes care of the fossil vertebrate collection of the museum with dedication and diligence.

\section{DESCRIPTION}

\section{SKULL}

The anatomical description of Pepesuchus deiseae is based primarily on the holotype (MN 7005-V), with many additional information on the rostrum and mandible from the paratype (MCT 1788-R). Although crushed and distorted during fossilization, the skull of the holotype is well preserved. The left lateral side of the postorbital region and the tip of the snout are missing, the latter is only known by fragments of the premaxilla.

The skull is triangular in dorsal view and the cranial table is nearly as wide as the ventral part. The bones of the cranial table (e.g., frontal, parietal, squamosal) are heavily ornamented with large and deep pits, while at the rostrum this ornamentation is less conspicuous (Figs. 1-3). The rostrum is slightly broad, has the dorsal surface slightly concave and comprises about $65 \%$ of the total skull length. The anteriormost region of the snout is pointed upward.

The upper temporal fenestra has a sub-elliptical outline and is formed by the parietal, squamosal, frontal, and postorbital. This opening is slightly smaller than the orbit and has a smooth inner surface. The orbit is elliptical and is placed laterally on the skull, with a slight dorsal inclination. Although reduced, the antorbital fenestra in this taxon is larger in respect to the orbit when compared with other peirosaurids (e.g., Lomasuchus).

The unpaired parietals form a single T-shaped element, in which the anteriormost branch is thinner and spreads out laterally at the contact with the frontal. The parietal forms most of the medial margin and half of the posterior border of the upper temporal fenestra. This general morphology resembles the one of some Sebecia (sensu Larsson and Sues 2007), like Lomasuchus palpebrosus Gasparini, Chiappe \& Fernandez, 1991, Montealtosuchus and, especially, Hamadasuchus rebouli Larsson \& Sues, 2007. The posterior margin of the parietal is slightly concave in occipital view, and no distinctive ridges or crests are present, contrary to the condition observed in Sebecus icaeorhinus Simpson 1937 (Colbert 1946). The frontoparietal suture is located between the upper temporal fenestrae and both bones are subequal in width.

The squamosal is sub-trapezoidal in dorsal view similar to Lomasuchus and Hamadasuchus, but different from Uberabasuchus where this bone is subtriangular. This heavily sculptured element forms the dorsal border of the optic cavity and the posterior half of the upper temporal fenestra lateral margin. Posteriorly, the squamosal shows an unsculptured process that extends posterolaterally. The tip of this process is slightly rectangular and less robust than in any other peirosaurid. In occipital view, it is possible to note that the squamosal extends further posteriorly than the paraoccipital process and the occipital condyle. The dorsal surface of the squamosal is flat, without a central depression, the latter present in Uberabasuchus. A wellmarked groove is observed on the lateral border of this 


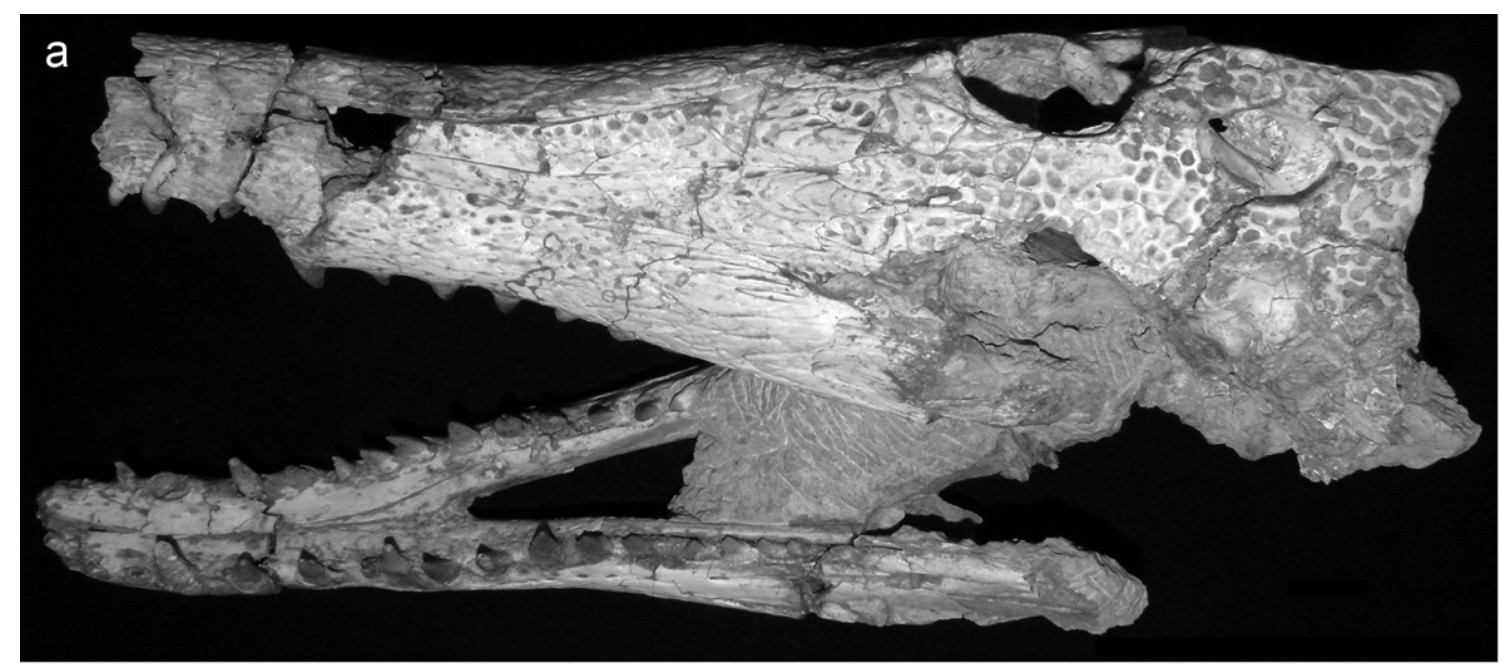

b

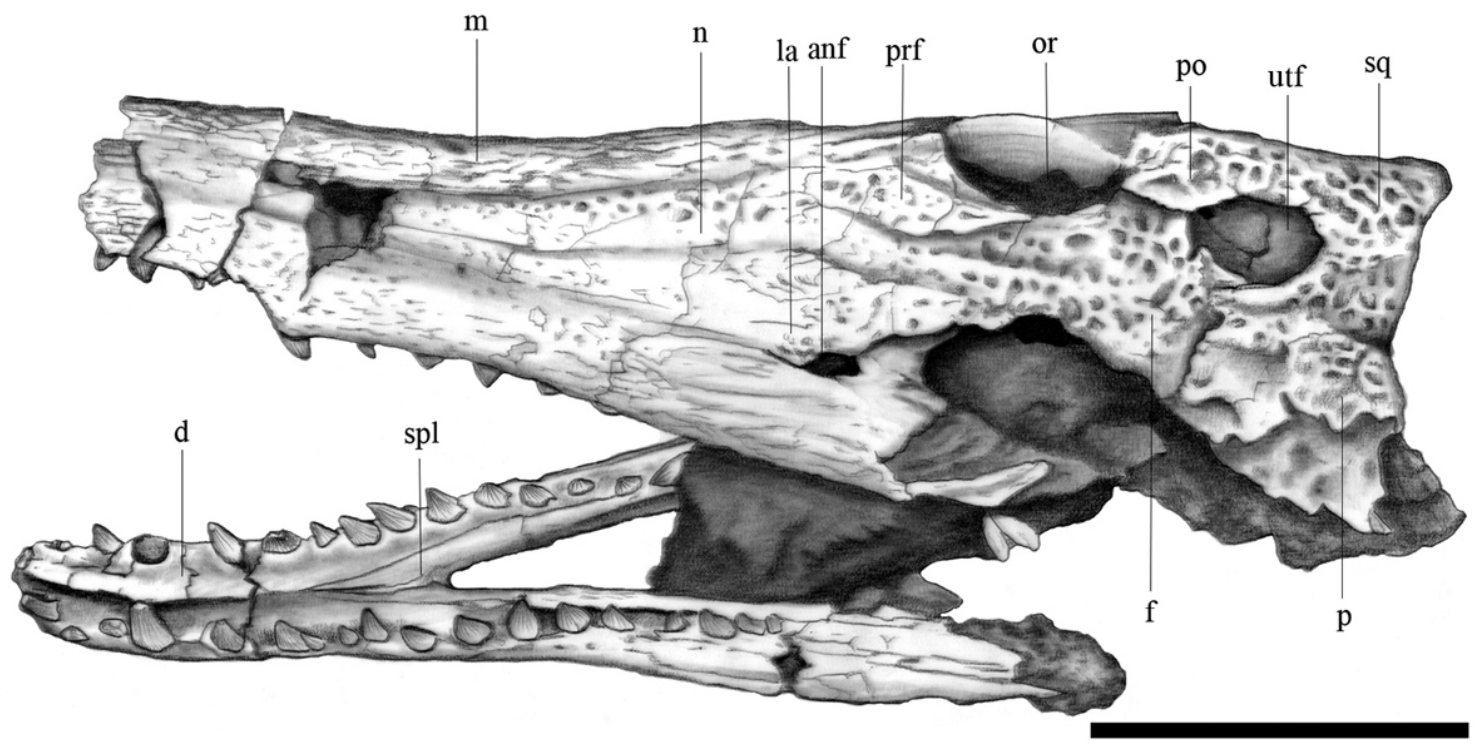

Fig. 1 - Dorsal view of skull and mandible of the holotype (MN $7005-$ V) of the crocodyliform Pepesuchus deiseae gen. et sp. nov. Scale bar: $100 \mathrm{~mm}$. Abbreviations: anf - antorbital fenestra, $\mathrm{d}$ - dentary, $\mathrm{f}$ - frontal, la - lacrimal, $\mathrm{m}$ - maxilla, $\mathrm{n}$ - nasal, or - orbit, $\mathrm{p}-\mathrm{parietal}$, po - postorbital, prf - prefrontal, spl - splenial, sq - squamosal, utf - upper temporal fenestra.

bone, extending over the external auditory meatus, suggesting the presence of an epidermal flap as seen in extant eusuchians.

In dorsal view, the postorbital is anteroposteriorly elongated, with the anterior portion expanded and showing two processes. The anterolateral process is reduced as in other peirosaurids, but the anteromedial process is comparatively more developed, forming the anterior margin of the upper temporal fenestra. As in all peirosaurids, this bone is placed medially relative to the ju- gal. The processes on the corners of the anterior margin of the postorbital are to some extent similar to those of some dyrosaurid species (Jouve 2005, Jouve et al. 2006, Barbosa et al. 2008). Pepesuchus also has a prominent depression on the anterolateral portion of the postorbital suggesting the presence of palpebral bones. This bone in the new taxon differs from the one of Uberabasuchus and Montealtosuchus, which is longer, with a prominent inward projection towards the frontal.

The completely fused frontals form a highly orna- 


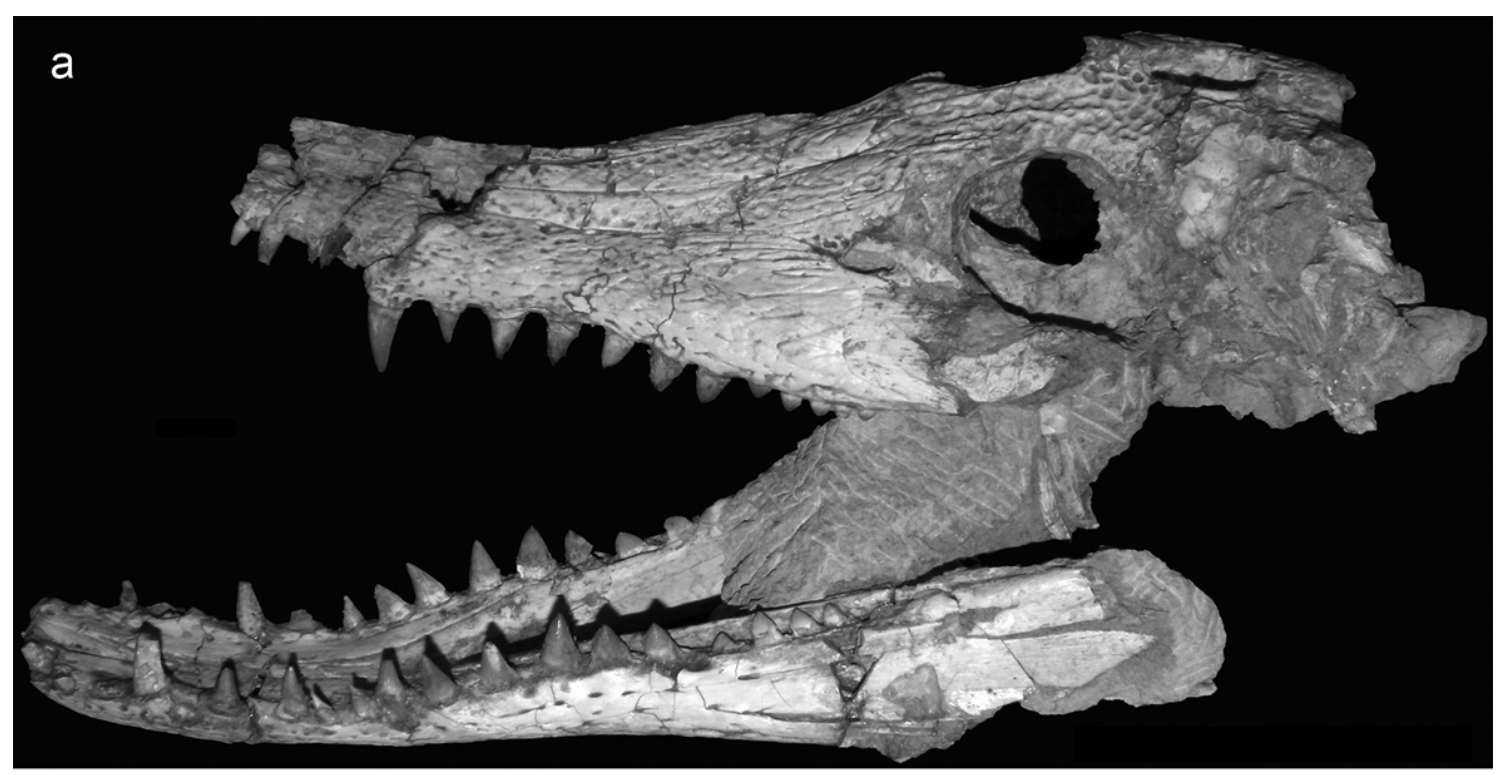

b

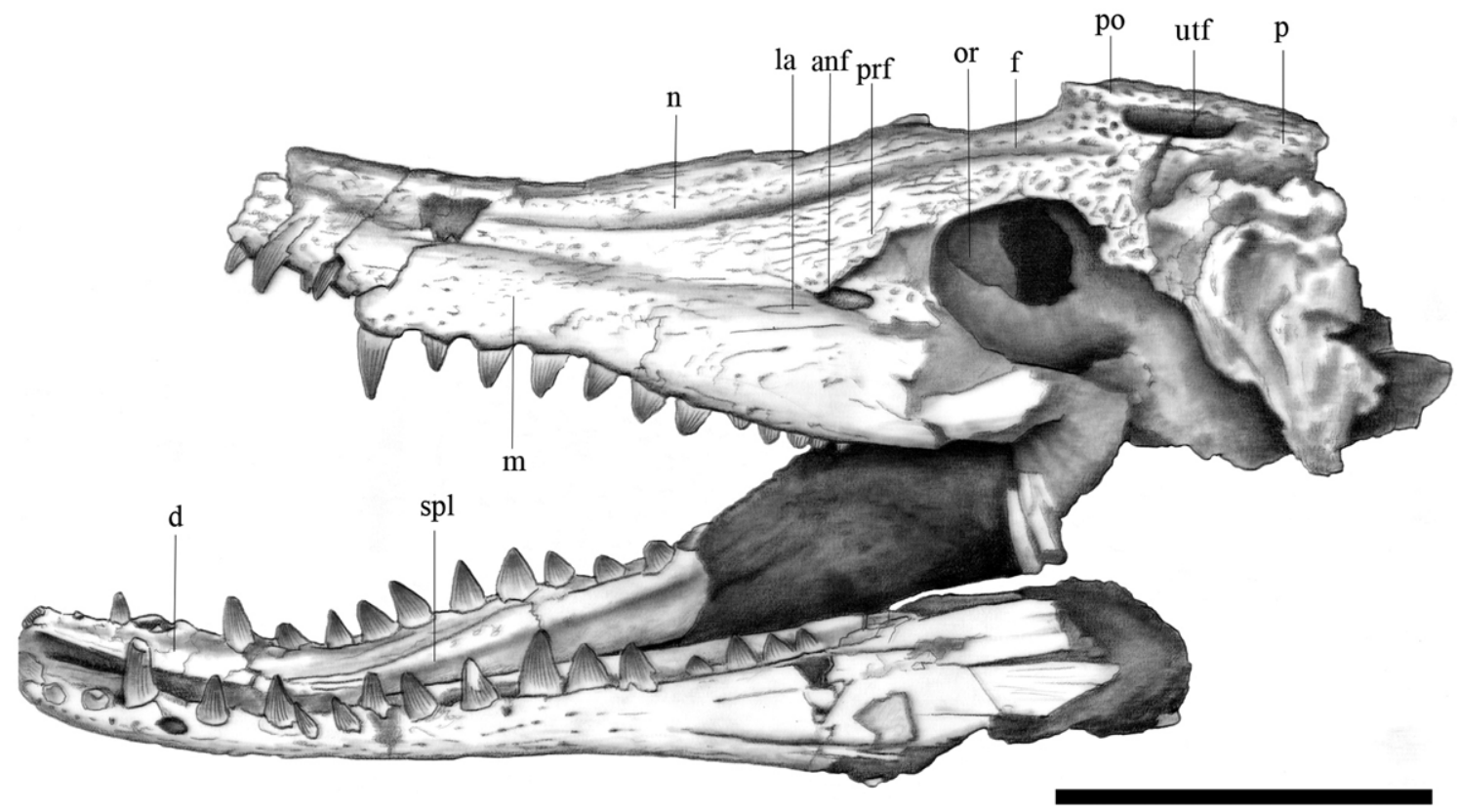

Fig. 2 - Lateral view of skull and mandible of the holotype (MN $7005-$ V) of the crocodyliform Pepesuchus deiseae gen. et sp. nov. Scale bar: $100 \mathrm{~mm}$. Abbreviations: anf - antorbital fenestra, $\mathrm{d}$ - dentary, $\mathrm{f}$ - frontal, la - lacrimal, $\mathrm{m}$ - maxilla, $\mathrm{n}$ - nasal, or - orbit, $\mathrm{p}$ - parietal, po - postorbital, prf - prefrontal, spl - splenial, utf - upper temporal fenestra.

mented, sub-triangular plate whose lateral edges articulate with the postorbitals, similar to extant crocodyliforms such as Crocodylus and Mecistops. The suture between the frontal and the parietal is rather straight, like in Hamadasuchus, Montealtosuchus and Lomasuchus, but different from the concave condition observed in Uberabasuchus and the festooned posterior margin of Sebecus. There is a low crest in the center of the frontal running throughout the entire length between the orbit, which was also reported in Lomasuchus and in other South American mesoeucrocodylians (Gasparini et al. 1991). Some Hamadasuchus specimens also have low 

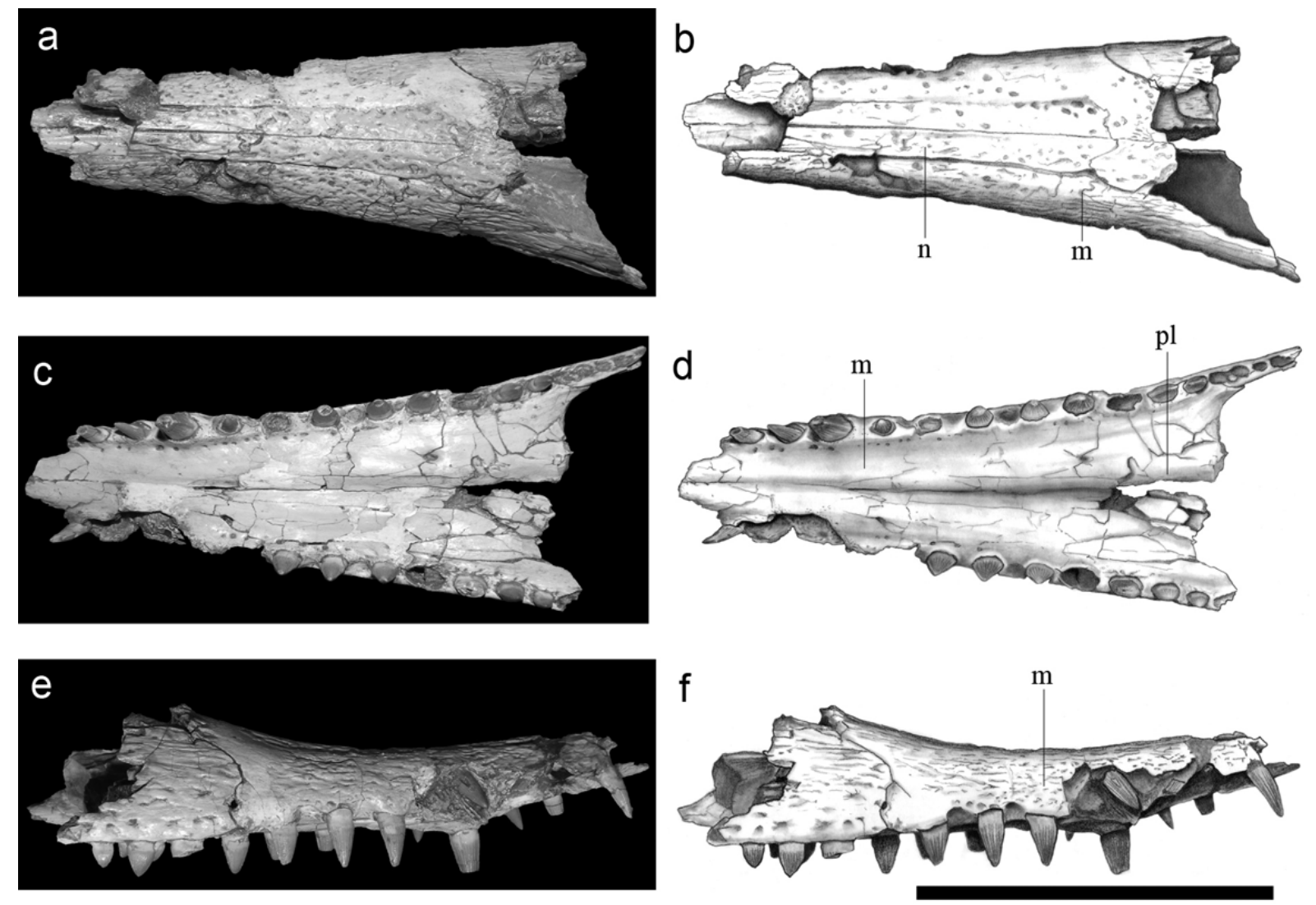

Fig. 3 - Paratype (MCT 1788 - R) of Pepesuchus deiseae gen. et sp. nov. in dorsal, ventral and lateral views. Scale bar: $100 \mathrm{~mm}$. Abbreviations: $\mathrm{m}$ - maxilla, $\mathrm{n}$ - nasal, $\mathrm{pl}$ - palatine.

crests on the dorsal surface of the frontal, but these are located more posteriorly, close to the contact with the parietal. The anterior end of the frontal is very acute, tapering between the prefrontals and the posterior processes of the nasals and differing therefore from other Sebecia where this bone generally has straight anterior margins.

The prefrontals are diamond-shaped, much longer than wide. They are reduced posterolaterally, forming the rim of the orbits. There is no fossa between the lacrimals. Like in Lomasuchus and Hamadasuchus the nasoprefrontal suture in Pepesuchus forms a gently curve with the concavity directed posterolaterally. This differs from the irregular nasoprefrontal suture without a clear curvature found in Peirosaurus and Uberabasuchus. In Montealtosuchus this suture is rather convex and directed posterolaterally. In Sebecus, the nasal forms a shallow concavity that borders the anterior margin of the prefrontal. The posterior contact between the prefrontal and the lacrimal bears a triangular depression, which extends into a groove along the lateral margin of the frontal.

The lacrimals are more dorsoventrally flattened in comparison with those of other peirosaurids (Fig. 2). The height of these bones is approximately $40 \%$ that of the orbit, which is a unique feature of this new crocodyliform. The lacrimals contact the nasals only in their dorsal border as in Hamadasuchus and Montealtosuchus, forming a comparatively larger suture than in Uberabasuchus, while in Peirosaurus, Lomasuchus and Mahajangasuchus there is no contact between these bones. The nasolacrimal suture is straight and sub-equal in length to the nasoprefrontal suture. In Hamadasuchus and Montealtosuchus the former contact is slightly shorter than the latter. The lacrimal bone of Pepesuchus comprises the total length of the dorsal border of the antorbital fenestra, which is also the case of Hamadasuchus and Uberabasuchus. 
The jugal displays a conspicuous ornamentation with large pits. The anterior process is dorsoventrally twice as tall as the posterior one. This feature is also present in Sebecus, Hamadasuchus, Lomasuchus, and Uberabasuchus. The orientation of the posterior process of the jugal that forms the lower margin of the orbit is straight, similar to the condition observed in Sebecus and Hamadasuchus, differing from the ventrally directed condition observed in Uberabasuchus and Lomasuchus, and the strongly arched condition of Mahajangasuchus. Montealtosuchus shows a thinner jugal with anterior and posterior processes sub-equal in width and sub-parallel.

The postorbital process of the jugal is a rod-like bone with an oval cross-section. It is directed posterodorsally and forms the base of the postorbital bar like in most other Sebecia, except for Uberabasuchus, which presents the base of the postorbital bar in strict dorsal orientation, such as observed in some basal crocodyliforms (e.g., Sphenosuchia and Protosuchia), and eusuchians (e.g., Crocodylus). The jugal of Pepesuchus extends rostrally in front of the prefrontal, what has only previously been observed in Stolokrosuchus lapparenti Larsson \& Gado, 2000, and in a few neosuchians (e.g., Elosuchus).

The anteriorly inclined dorsal head is the only preserved part of the quadrate. This bone forms the ventral border of the tympanic cavity and contacts the squamosal broadly. As in Hamadasuchus, Mahajangasuchus, and Montealtosuchus, the quadrate contacts the otoccipital laterally to the cranioquadrate passage. There are two low crests in the anterior ascending branch of the quadrate, almost inside the tympanic cavity, but no evidence of any fenestrae.

Overall the snout is narrow and platyrostral (MCT 1788 -R). It comprises about $65 \%$ of the total skull length and has a width/length ratio of about 1.8, similar to Hamadasuchus, Lomasuchus and Montealtosuchus. As in all other sebecian crocodyliforms (but not in Stolokrosuchus), the maxilla is festooned.

The nasals are rectangular, with sub-parallel margins that taper anteriorly. This configuration is common in Sebecia, but differs from the notosuchian triangular outline (e.g., Mariliasuchus and Notosuchus). The nasals are unfused, as in Hamadasuchus, Uberabasuchus, Mon- tealtosuchus, and Lomasuchus, and differ from Mahajangasuchus and Kaprosuchus in which they fuse into a single element. The lateral exposure of these bones is minimal, similarly to Stolokrosuchus, Lomasuchus and Montealtosuchus, and differ from the larger exposure of those bones observed in Uberabasuchus and Hamadasuchus.

The premaxilla is incomplete. The outline of this bone suggests a small oval opening that is laterally exposed. It is possible to observe the perinarial fossa beneath the external nares, which is a feature present in sebecians and notosuchians (including baurusuchids). There are five premaxillary teeth, with the two first ones almost confluent (MN 7005-V), features are regarded as peirosaurid synapomorphies (Larsson and Sues 2007). Posterior to the fifth premaxillary tooth there is a constriction that indicates the presence of a notch between the maxilla and the premaxilla (MCT 1788-R).

The suture between the palatine and the maxilla is V-shaped (MN 7005-V), similarly to neosuchian and eusuchian crocodyliforms. The contact between these two bones is M-shaped in Hamadasuchus and Montealtosuchus, and U-shaped in Lomasuchus. There is a slight sagittal torus on maxillary palatal shelves that is regarded as a diagnostic character of sebecian crocodyliforms (Larsson and Sues 2007).

The ectopterygoid is long and elliptical, extending posteriorly along the ventral surface of the jugal and forming the postorbital bar. This is not observed in other sebecians (e.g., Hamadasuchus and Sebecus), but has been reported in several mesoeucrocodylians such as Araripesuchus, Notosuchus, and Trematochampsa. Anteriorly, the ectopterygoid contacts the maxilla close to the last maxillary alveoli, as in Hamadasuchus, differing from the condition observed in Sebecus and Lomasuchus.

The pterygoids are damaged and their wings are broken. The contact with the palatines limits both the lateral border of the choana and the medial border of the palatal fenestra. There is no bone wall or intumescence delimiting the posterior margin of the choana, which is the plesiomorphic condition of non-neosuchian mesoeucrocodylians. Furthermore, there is no developed septum made by this bone directed into the choanae, as in Hamadasuchus and Montealtosuchus, but only a thin 
bone bar. The posteromedial region of the pterygoid is visible in occipital view, close to the basioccipital plane, as in Hamadasuchus and Lomasuchus.

There is a limited dorsal exposition of the supraoccipital, as in Montealtosuchus (also occurring in the baurusuchids, e.g., Stratiotosuchus). Other sebecians like Hamadasuchus, Uberabasuchus, Stolokrosuchus, and Lomasuchus have no dorsal exposure of this bone. There are two marked depressions for the neck articulation located at the base of the postoccipital processes, as in Hamadasuchus.

The exoccipital borders the foramen magnum and contacts the basioccipital. Its ventromedial portion bears two foramina placed side by side. The medial one is the aperture for the XII ${ }^{\text {th }}$ (hypoglossal) cranial nerve, and the lateral one is the larger foramen vagi, which is the exit of cranial nerves IX, X and XI. The foramen for the posterior carotid artery is placed below these, similar to Montealtosuchus and Lomasuchus. Mahajangasuchus differs by having four different foramina for the cranial nerves and the carotid artery passage well marked in this region.

The basioccipital and the occipital surfaces as a whole present a marked slope with posteroventrally orientation, differing from the verticalized condition present in extant eusuchians. The basisphenoid is exposed on the ventral surface of the braincase. It presents no ridges on its ventral surface, as in Sebecus and Mahajangasuchus. In occipital view, the basisphenoid is broadly exposed, beneath the basioccipital and close to the median Eustachian foramen.

\section{MANDIBLE}

The lower jaw bones are slender, delicate, and relatively short. The dentaries and splenials form a moderately long mandibular symphysis, comprising $36 \%$ of the mandible length. The splenials contribute extensively to the symphysis, with more than $20 \%$ of its total length. Except for Stolokrosuchus, which is a long-snouted sebecian, all other members of this clade (e.g., Sebecus, Montealtosuchus, Uberabasuchus, Lomasuchus) have short and deep symphysis. The general morphology of the mandible is very similar to Itasuchus, which is bigger and very robust. This taxon was once considered as also present in the Araripe basin (Buffetaut 1991), but this has been refuted since (Kellner 1987, 1994). The presence of a conspicuous enlargement in the region of the fourth dentary tooth in Itasuchus also differentiates these taxa. A long and shallow groove runs along the lateral surface of the dentary, below the alveolar margin, as in extant eusuchians.

\section{DENTITION}

There are 17 subcircular maxillary teeth preserved in MCT 1788-R, which is the second highest number of teeth recorded in a sebecian species, only lower than the long-snouted Stolokrosuchus. The closely related $\mathrm{Ma}$ hajangasuchus and Kaprosuchus are the sebecians with fewer teeth, presenting no more than 11 maxillary teeth. There are five small subcircular teeth in the premaxilla, with the two first ones placed close to each other in near confluent alveoli. These two characters are traditional synapomorphies of the clade Peirosauridae (Gasparini 1982). There are 18 teeth in the dentary, with the most anterior ones directed anterodorsally and more slender and elongated than in other peirosaurids.

All teeth are smooth bicarinate, with striated external surfaces and well-marked longitudinal lines. The crowns lacking serrations are a distinctive feature of this species since most sebecians present ziphodont dentition, with lateral compression and chisel-like denticles.

Some of the dentary alveoli placed at middle symphyseal length are disposed in a peculiar fashion. The $6^{\text {th }}$ and $7^{\text {th }}$ alveoli are very close to each other, forming a couplet, but with a complete interalveolar wall between both. The same occurs with the next alveolar pair, $8^{\text {th }}$ and $9^{\text {th }}$. Both couplets are separated from each other by a small diastema equivalent in length to the anteroposterior diameter of its larger alveoli (the $6^{\text {th }}$ and $9^{\text {th }}$, respectively). A similar arrangement of the middle symphyseal teeth occurs in the holotype of Itasuchus jesui$n o i$, involving different alveolar pairs $\left(5^{\text {th }}\right.$ and $6^{\text {th }}, 7^{\text {th }}$ and $\left.8^{\text {th }}\right)$.

\section{DISCUSSION}

The current phylogenetic proposal regarding cretaceous mesoeucrocodylians is disputed, including the monophyly of the Peirosauridae. Introduced by Gasparini (1982), this clade traditionally comprises terrestrial South American crocodyliforms with ziphodont denti- 
tion and oreinirostral skulls. The recognition of African peirosaurids, such as Hamadasuchus rebouli from Morocco (Upper Cretaceous Kem Kem Beds) and Stolokrosuchus lapparenti from Niger (Lower Cretaceous El Rhaz Formation), indicates that the Peirosauridae had a Gondwanan distribution (Larsson and Gado 2000, Larsson and Sues 2007).

A peirosaurid group that includes Peirosaurus, Lomasuchus and Uberabasuchus is well established, and its affinities with Hamadasuchus and Montealtosuchus is supported by several authors (Carvalho et al. 2004, Larsson and Sues 2007, Jouve 2009, Turner and Sertich 2010). Larsson and Sues (2007) define the Peirosauridae on the basis of five unambiguous synapomorphies, and three of them are present in Pepesuchus deiseae: the oval cross-section of jugal along the lower temporal bar, the presence of five premaxillary teeth, and the anterior two premaxillary alveoli nearly confluent.

The major issue about the monophyly of the Peirosauridae is the inclusion of Stolokrosuchus, but according to Larsson and Sues (2007) this taxon possesses all synapomorphies that diagnose this group. However, some recent phylogenetic hypotheses have contested the positioning of Stolokrosuchus within Peirosauridae, defending a closer relationship of this species with neosuchian crocodyliforms (e.g., Jouve 2009, Turner and Sertich 2010). The support of that relationship, however, is rather weak and based on the longirostrine condition of Stolokrosuchus (Clark 1994), a question that needs further studies and is beyond the scope of this paper.

The name Sebecia was proposed for a clade that includes Pabwehshi pakistanensis Wilson, Malkani \& Gingerich, 2001 from Pakistan (Upper Cretaceous Pab Formation), Peirosauridae and its sister-taxon Sebecidae (Larsson and Sues 2007). Pepesuchus deiseae has at least one unambiguous synapomorphy of this group, namely the presence of a sagittal torus on maxillary palatal shelves. A large foramen on the palatine-maxillae contact can be seen in MCT 1788-R, but not in MN 7005$\mathrm{V}$, and therefore it precludes the proper assignment of this sebecian synapomorphy for the new species. Pepesuchus also shares one synapomorphy with the unnamed clade formed by Sebecidae + Peirosauridae, which is the posteriormost premaxillary alveolus excavated by the premaxilla-maxilla lateral fossa.

The recent phylogenetic analysis by Turner and Sertich (2010) has the most complete sample of sebecianrelated species with Peirosaurus, Lomasuchus, Hamadasuchus, Montealtosuchus, Uberabasuchus, Mahajangasuchus, Kaprosuchus and Stolokrosuchus. They recognize a monophyletic Peirosauridae (but excluding Stolokrosuchus) on the basis of five unambiguous synapomorphies, and two of them are entirely unique to this clade: the wedge-like process of maxilla in lateral surface of premaxilla-maxilla suture and the presence of developed perinarial fossa, ventral to external naris. The latter character is present in Pepesuchus and is also considered a synapomorphy of Sebecia.

Some taxonomic definitions regarding the Peirosauridae are still not well established. The validity of Uberabasuchus terrificus has been questioned recently, since it comes from the same locality and deposits of Peirosaurus tormini (DGM 433-R) and, according to Larsson and Sues (2007), there are no characters that distinguish both species (see general discussion about species recognition in the fossil record by Kellner 2010). The Argentinean specimens currently assigned to Peirosaurus tormini (Upper Coniacian of Bajo de la Carpa Formation, sensu Calvo and Porfiri 2010) possibly constitute a distinct taxon (Martinelli unpublished data).

Pepesuchus deiseae presents several diagnostic features that are traditionally associated with Sebecia and Peirosauridae. The new set of characters reported here can help to improve our understanding of the relationships among these mesoeucrocodylians, especially regarding problematic species (e.g., Stolokrosuchus), and a comprehensive analyses including Pepesuchus deiseae and the postcranial information (not addressed here) will add to the comprehension of the evolutionary history of gondwanan crocodyliforms.

\section{ACKNOWLEDGMENTS}

Rodrigo Machado (Departamento Nacional de Produção Mineral, Rio de Janeiro) and Maurilio Oliveira (Museu Nacional/UFRJ) are thanked for help in the DNPM/ $\mathrm{RJ}$ collections and for the illustrations of specimens, respectively. We thank Agustín Martinelli (UFTM) and an anonymous reviewer for the critical revision improved 
this manuscript. The Conselho Nacional de Desenvolvimento Científico e Tecnológico is thanked for the fellowship (CNPq \#140812/2007-5) to GRO. This study was partially funded by the Fundação Carlos Chagas Filho de Amparo à Pesquisa do Estado do Rio de Janeiro (FAPERJ \#E-26/102.779/2008) and the Conselho Nacional de Desenvolvimento Científico e Tecnológico (CNPq \#307276/2009-0) grants to AWAK, and the Fundação de Amparo à Pesquisa do Estado de Minas Gerais (FAPEMIG \#APQ-00581-09) for the grant to DR.

\section{RESUMO}

Um novo crocodilomorfo da Formação Presidente Prudente, Cretáceo Superior (Campaniano-Maastrichtiano) do Grupo Bauru é descrito com base em dois exemplares, consistindo de crânio e mandíbulas quase completos. O material é procedente da localidade conhecida como "Tartaruguito", situada em um antigo ramal ferroviário que ligava as cidades de Pirapozinho e Presidente Prudente, Estado de São Paulo, Brasil. A nova espécie, denominada de Pepesuchus deiseae gen. et sp. nov., é classificada no clado Peirosauridae, com base em três sinapomorfias: presença de cinco dentes pré-maxilares, os dois primeiros alvéolos da pré-maxila quase confluentes e a secção transversal do jugal ao longo da barra temporal inferior oval. O novo táxon aumenta a marcante diversidade de crocodiliformes do Grupo Bauru e dos Peirosauridae, que poderá vir a ser um dos clados mais representativos de mesoeucrocodilianos gondwânicos.

Palavras-chave: Pepesuchus, Peirosauridae, Cretáceo, Grupo Bauru, Brasil.

\section{REFERENCES}

Andrade MB And Bertini RJ. 2008. A new Sphagesaurus (Mesoeucrocodylia: Notosuchia) from the Upper Cretaceous of Monte Alto City (Bauru Group, Brazil), and a revision of the Sphagesauridae. Hist Bio 20: 101-136.

Barbosa A, Kellner AWA and Viana MSS. 2008. New dyrosaurid crocodylomorph and evidences for faunal turnover at the K-P transition in Brazil. Proc R Soc B 275: 1385-1391.

Bertini RJ, Santucci RM, Toledo CEV and MeneGAZZO MC. 2006. Taphonomy and depositional history of an Upper Cretaceous turtle-bearing outcrop from the Adamantina Formation, Southwestern São Paulo State. Rev Bras Paleontol 9: 181-186.
Buffetaut E. 1991. Itasuchus Price 1955. In: MAISEY JG (Ed), Santana Fossils: An Illustrated Atlas. T. F. H. Publications, Neptune, New Jersey, p. 348-350.

CAlvo JO AND PORFIRI JD. 2010. New material of peirosaurids from Neuquén, Patagonia: its age. Bra Geo Journal 1: 50-64.

Campos DA, Suarez JM, Riff D and Kellner AWA. 2001. Short note on a new Baurusuhidae (Crocodyliformes, Metasuchia) from the Upper Cretaceous of Brazil. Bol Mus Nac, Geol 57: 1-7.

CAndeiro CRA And Martinelli AG. 2006. A review of paleogeographical and chronostratigraphical distribution of mesoeucrocodylian species from the Upper Cretaceous beds from the Bauru (Brazil) and Neuquén (Argentina) groups, Southern South America. J South Am Earth Sci 22: $116-129$.

CARVAlho IS AND Bertini RJ. 1999. Mariliasuchus: um novo Crocodylomorpha (Notosuchia) do Cretáceo da Bacia Bauru, Brasil. Geol Colomb 24: 83-105.

Carvalho IS, Ribeiro LCB And Avilla LS. 2004. Uberabasuchus terrificus sp. nov. a new Crocodylomorpha from the Bauru Basin (Upper Cretaceous), Brazil. Gondwana Res 7: 975-1002.

CARVAlho IS, VAsconcellos FM And TAVAREs SAS. 2007. Montealtosuchus arrudacamposi, a new peirosaurid crocodile (Mesoeucrocodylia) from the Late Cretaceous Adamantina Formation of Brazil. Zootaxa 1607: 35-46.

Clark JM. 1994. Patterns of evolution in Mesozoic Crocodyliformes. In: FRASER NC AND SUES HD (Eds), In the Shadow of the Dinosaurs, Early Mesozoic Tetrapods, New York: Cambridge University Press, New York, USA, p. 84-97.

Colbert EH. 1946. Sebecus, representative of a peculiar suborder of fossil Crocodilia from Patagonia. B Am Mus Nat His 87: 217-170.

Dias-Brito D, Musacchio EA, Castro JC, MaranHÃo MSA, SuÁrez JM AND Rodrigues R. 2001. Grupo Bauru: uma unidade continental do Cretáceo do Brasil - concepções baseadas em dados micropaleontológicos, isotópicos e estratigráficos. Rev Paléobiologie 20: 245-304.

Fernandes LA And Coimbra AM. 1996. A Bacia Bauru (Cretáceo Superior, Brasil). An Acad Bras Cienc 68: 95105.

FERnANDEs LA AND CoIMBRA AM. 2000. Revisão estratigráfica da parte oriental da Bacia Bauru (Neocretáceo). Rev Bras Geoc 30: 145-158. 
GASPARINI Z. 1982. Una nueva familia de cocodrilos zifodontes cretácicos de América del Sur. Actas V Cong Latinoamer Geol 4: 317-329.

Gasparini Z, Chiappe LM and Fernandez M. 1991. A new Senonian peirosaurid (Crocodylomorpha) from Argentina and a synopsis of the South American Cretaceous crocodilians. J Vert Paleontol 11: 316-333.

IORI FV AND CARVALHO IS. 2009. Morrinhosuchus luziae, um novo Crocodylomorpha Notosuchia da Bacia Bauru, Brasil. Rev Bras Geoc 39: 717-725.

Jouve S. 2005. A new description of Dyrosaurus phosphaticus (Thomas 1893) (Mesoeucrocodylia: Dyrosauridae) from the Lower Eocene of North Africa. Can J Earth Sci 42: 323-337. (doi:10.1139/E05-008)

Jouve S. 2009. The skull of Teleosaurus cadomensis (Crocodylomorpha, Thalattosuchia), and phylogenetic analysis of Thalattosuchia. J Vert Paleontol 29: 88-102.

Jouve S, Iarochene M, Bouya B and Amaghzaz M. 2006. A new species of Dyrosaurus (Crocodylomorpha, Dyrosauridae) from the early Eocene of Morocco: phylogenetic implications. Zoolog J Linnean Soc 148: 603656.

KELLNER AWA. 1987. Ocorrência de um novo crocodiliano no Cretáceo Inferior da Bacia do Araripe, Nordeste do Brasil. An Acad Bras Cienc 59: 219-232.

KelLner AWA. 1994. Comments on the paleobiogeography of Cretaceous archosaurs during the opening of the South Atlantic Ocean. Acta Geol Leopold 39: 615-625.

Kellner AWA. 1998. Panorama e perspectiva do estudo de répteis fósseis no Brasil. An Acad Bras Cienc 70: 647676.

Kellner AWA. 2010. Comments on the Pteranodontidae (Pterosauria, Pterodactyloidea) with the description of two new species. An Acad Bras Cienc 82: 1063-1084.

Kellner AWA AND CAMpos DA. 1999. Vertebrate paleontology in Brazil - a review. Episodes 22: 238-251.

Kellner AWA, Pinheiro AEP, Azevedo SAK, HenRiQues DDR, CARVAlho LB AND Oliveira G. 2009. A new crocodyliform from the Alcântara Formation (Cenomanian), Cajual Island, Brazil. Zootaxa 2030: 49-58.

LARSSON H AND GADO B. 2000. A new early Cretaceous crocodyliform from Niger. Neues Jahrb Geol P-A: 217: 131-141.
LARSSON H AND SUES HD. 2007. Cranial osteology and phylogenetic relationships of Hamadasuchus rebouli (Crocodyliformes: Mesoeucrocodylia) from the Cretaceous of Marocco. Zoolog J Linnean Soc 149: 533-567.

NAscimento PM AND ZAHER H. 2010. A new species of Baurusuchus (Crocodyliformes, Mesoeucrocodylia) from the Upper Cretaceous of Brazil, with the first complete postcranial skeleton described from the family Baurusuchidae. Pap Avul Zool 50: 323-361.

PoL D. 2003. New remains of Sphagesaurus (Crocodylomorpha: Mesoeucrocodylia) from the Upper Cretaceous of Brazil. J Vert Paleontol 23: 817-831.

PRICE LI. 1945. A new reptil from the Cretaceous of Brazil. Div Geo Min, Est Not Prel 25: 1-8.

Price LI. 1950. Os crocodilídeos da fauna da Formação Bauru do Cretáceo terrestre do Brasil Meridional. An Acad Bras Cienc 22: 77-83.

PRICE LI. 1955. Novos crocodilídeos dos arenitos da série Baurú Cretáceo do Estado de Minas Gerais. An Acad Bras Cienc 27: 487-498.

RicCOMini C. 1997. Arcabouço estrutural e aspectos do tectonismo gerador e deformador da Bacia Bauru no Estado de São Paulo. Rev Bras Geoc 27: 153-162.

Romano PSR And AzEvedo SAK. 2007. Morphometric analysis of the Upper Cretaceous Brazilian side-necked turtle Bauruemys elegans (Suárez 1969) (Pleurodira, Podocnemididae). Arq Mus Nac 65: 395-402.

SoARES PC, LANDIM PMB, FÚlFARO VJ AND SOBREIRONeto AF. 1980. Ensaio de caracterização estratigráfica do Cretáceo no Estado de São Paulo: Grupo Bauru. Rev Bras Geoc 10: 177-185.

SuÁrez JM. 1969. Um quelônio da Formação Bauru. In: Anais do $23^{\text {th }}$ Congresso Brasileiro de Geologia 23, Salvador, Bahia, Brasil. Anais, SBG, p. 167-176.

Turner AH And Sertich JJW. 2010. Phylogenetic history of Simosuchus clarki (Crocodyliformes: Notosuchia) from the Late Cretaceous of Madagascar. J Vert Paleontol 30: $177-236$.

Zaher H, Pol D, Carvalho AB, Riccomini C, CamPOS DA AND NAVA W. 2006. Redescription of the cranial morphology of Mariliasuchus amarali, and its phylogenetic affinities (Crocodyliformes, Notosuchia). Am Mus Nov 3512: 1-40. 